\title{
Estimating Probable Maximum Precipitation for Linau River Basin in Sarawak
}

\author{
M. Hussain, S. Nadya and F.J. Chia \\ Hydropower Development Division, Sarawak Energy Berhad, 93050, Kuching, Sarawak, Malaysia \\ Date Received: 3 October 2014 \\ Date Published: 30 January 2015
}

\begin{abstract}
The probable maximum precipitation (PMP) is the greatest depth of precipitation for a given duration that is physically possible over a given size storm area at a particular geographical location at a certain time of the year. PMP is very important to be considered for the design of river regulating structures i.e Dams and Barrages to overcome any possible chance of overtopping failure as well as for public safety and hazards downstream of any of these structures. Especially if these structures located in the upstream of the of the populated town or city than the failure could damage severely such areas. As such the PMP convention is always a requirement as primary design dam/reservoir criteria when public safety is of concern. The PMP is used to derive Probable Maximum Flood (PMF), which further used in hydraulic modeling to check the impact assessments for such occasions. This paper focuses on estimation of PMP for Linau River Basin in Sarawak using statistical method proposed by World Meteorological Organization (WMO), which is described in its operational manual. Long Lidam and Long Laku are located in Linau River Basin but Long Laku has long discontinuity in the data set thus the rainfall series at Long Lidam is further used for PMP estimation. The missing data was in-filled using Belaga rain gauge station as Long Lidam rainfall has good correlation with Belaga rainfall data. Hershfield statistical method has been adopted to estimate the 24-hour duration PMP. The Probable Maximum Precipitation for 24-hour duration storm is estimated as $691 \mathrm{~mm}$ for the Linau River Basin.
\end{abstract}

Keywords: Linau River Basin, Probable Maximum Precipitation (PMP), Hershfield Statistical Method

\section{INTRODUCTION}

$\mathrm{P}$ robable Maximum Precipitation (PMP) is theoretically defined as the greatest depth of precipitation for a given duration which is physically possible over a given size storm area at a particular geographical location and at a particular time of year [1]. Hydrologists use a PMP magnitude to calculate the Probable Maximum Flood (PMF) in the case where the risk of a dam overtopping is deemed unacceptable.

Using the PMP for a generation of the PMF has become as a standard method for dam design in many parts of the world. Estimating the PMP in a place has variety of procedures based on location of the project basin, availability of data and other considerations have been proposed. Some are based on physical or meteorological analysis such as maximization and transposition of actual storms; whereas some are based on statistical analysis [2].

Sarawak has a reasonable hydropower potential on various river basins i.e Rajang River Basin, Baram River Basin, Limbang River Basin etc. Along with the river inflow yield assessment, it is also necessary to estimate the probable maximum flood for optimising the design of different hydropower and hydraulic structures. The purpose of this paper is to estimate PMP for Linau River Basin $\left(1725 \mathrm{~km}^{2}\right)$ located upstream of the Bakun Hydroelectric Project in upper Rajang River basin.

\section{MATERIALS AND METHODS}

\subsection{Study Area and Data}

Linau River Basin as illustrated in Figure 1 has an area of $1725 \mathrm{~km}^{2}$ located in the Upper Rajang Basin in Sarawak, which is the largest basin in the region and covers about $50000 \mathrm{~km}^{2}$. The catchment has great potential for hydropower generation due to its mountainous terrain and land surface elevation range from about $260 \mathrm{~m}$ to $1655 \mathrm{~m}$ above mean sea level.

Daily rainfall data were obtained from four selected stations in the Upper Rajang Basin, Sarawak which ranges from the period 1963 to 2013. However, none of the stations have complete dataset for the entire period due to gaps of missing data as tabulated in Table 1. Figure 1 shows the location of the four stations within and close to Linau River Basin which are

Mubasher Hussain is Senior Hydrologist in Hydropower Development Division, Sarawak Energy Berhad. (email: MubasherHussain@sarawakenergy.com.my).

Susie Nadya is Hydrologist in Hydropower Development Division, Sarawak Energy Berhad. (email: SusieNadya@sarawakenergy.com.my).

Chia Fuk Jing is Senior Hydrographer in Hydropower Development Division, Sarawak Energy Berhad. (email: fukjingc@sarawakenergy.com.my). 


\section{UNIMAS e-Journal of Civil Engineering}

maintained by Department of Irrigation (DID). Long Lidam and Long Laku are located in Linau River Basin but Long Laku has long discontinuity in the data set thus the rainfall series at Long Lidam is further used for PMP estimation.

Table 1 Rainfall Stations in the Upper Rajang River Basin (DID, 2013)

\begin{tabular}{lccccc}
\hline \multicolumn{1}{c}{ Station Name } & Station Number & Latitude & Longitude & Data Availability & Remark \\
\hline Belaga & 2737103 & 0024228 & 1134646 & $1963-2012$ & Discontinuous \\
Long Lidam & 2346001 & 0022015 & 1143850 & $1980-2013$ & Discontinuous \\
Long Laku & 2442001 & 0022820 & 1141410 & $1986-2013$ & Discontinuous \\
Long Luar & 2645001 & 0024125 & 1143103 & $1998-2013$ & Discontinuous \\
\hline
\end{tabular}

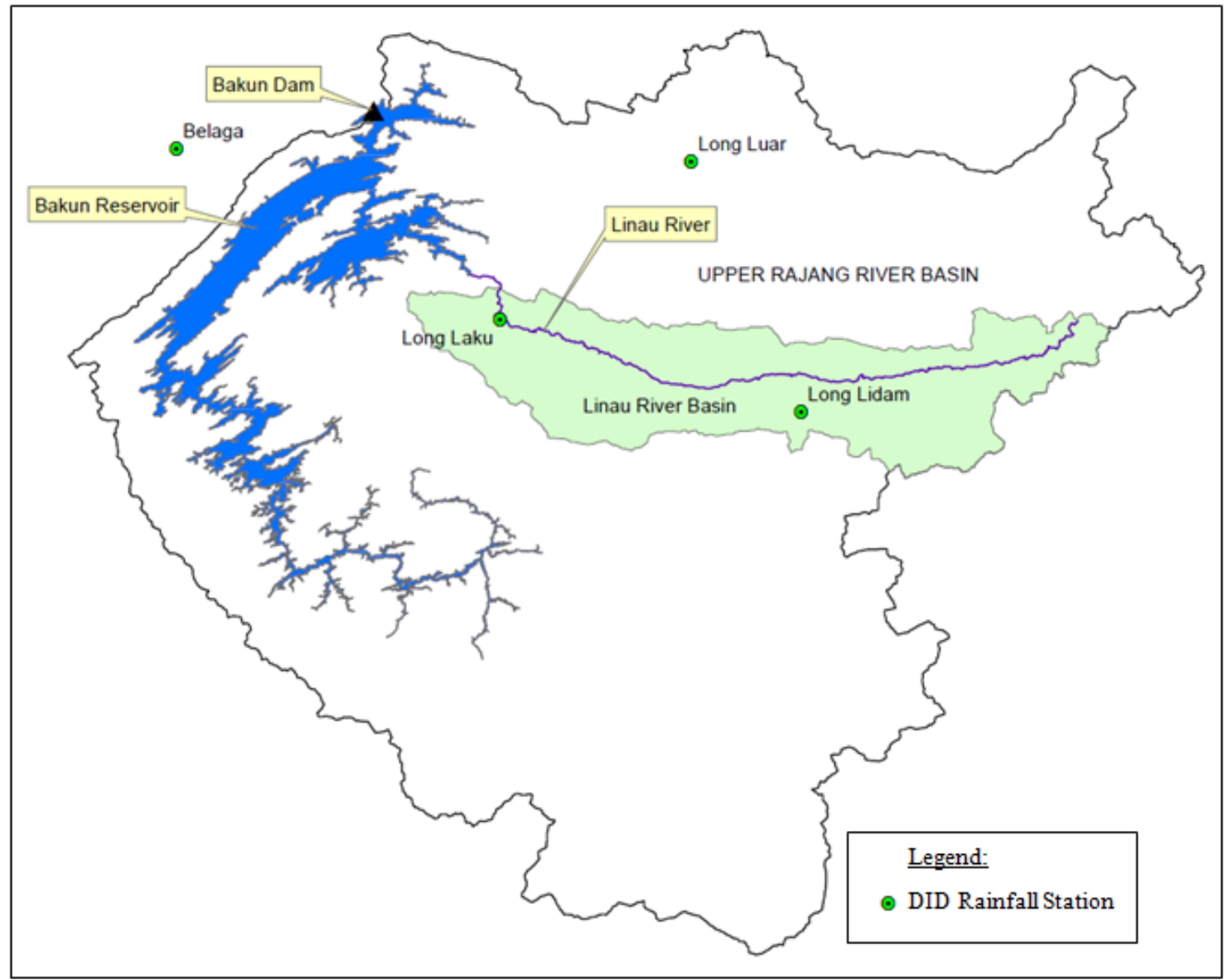

Figure 1 Location of the Selected Rainfall Stations

\subsection{Double Mass Curve}

Hydrologic data such as record of rainfall generally consist of a sequence of observations of some phase of the hydrologic cycle made at a particular rainfall station. Most hydrological analyses prefer long record of dataset which sometimes has greater chance of inconsistencies. The use of a double-mass curve is a convenient way to check the consistency of a record. It is considered as one of the first steps in the analysis of a long record, except when the scarcity of other old records makes it unfeasible. The theory of the double-mass curve is based on the fact that a graph of the cumulative of one quantity against the cumulative of another quantity during the same period will plot as a straight line so long as the data are proportional; the slope of the line will represent the constant of proportionality between the quantities [3].

The double mass curves have been plotted between the rainfall data for Long Lidam, Belaga, Long Laku and Long Luar rain gauge stations for the period of 2000 to 2009. All of these stations have consistent relation with Long Lidam rain rainfall data in double mass plots. The plot in Figure 2 shows that the Long Lidam rainfall data is consistent with the Belaga rainfall data which has already been checked and used for various studies [4], [5]. 


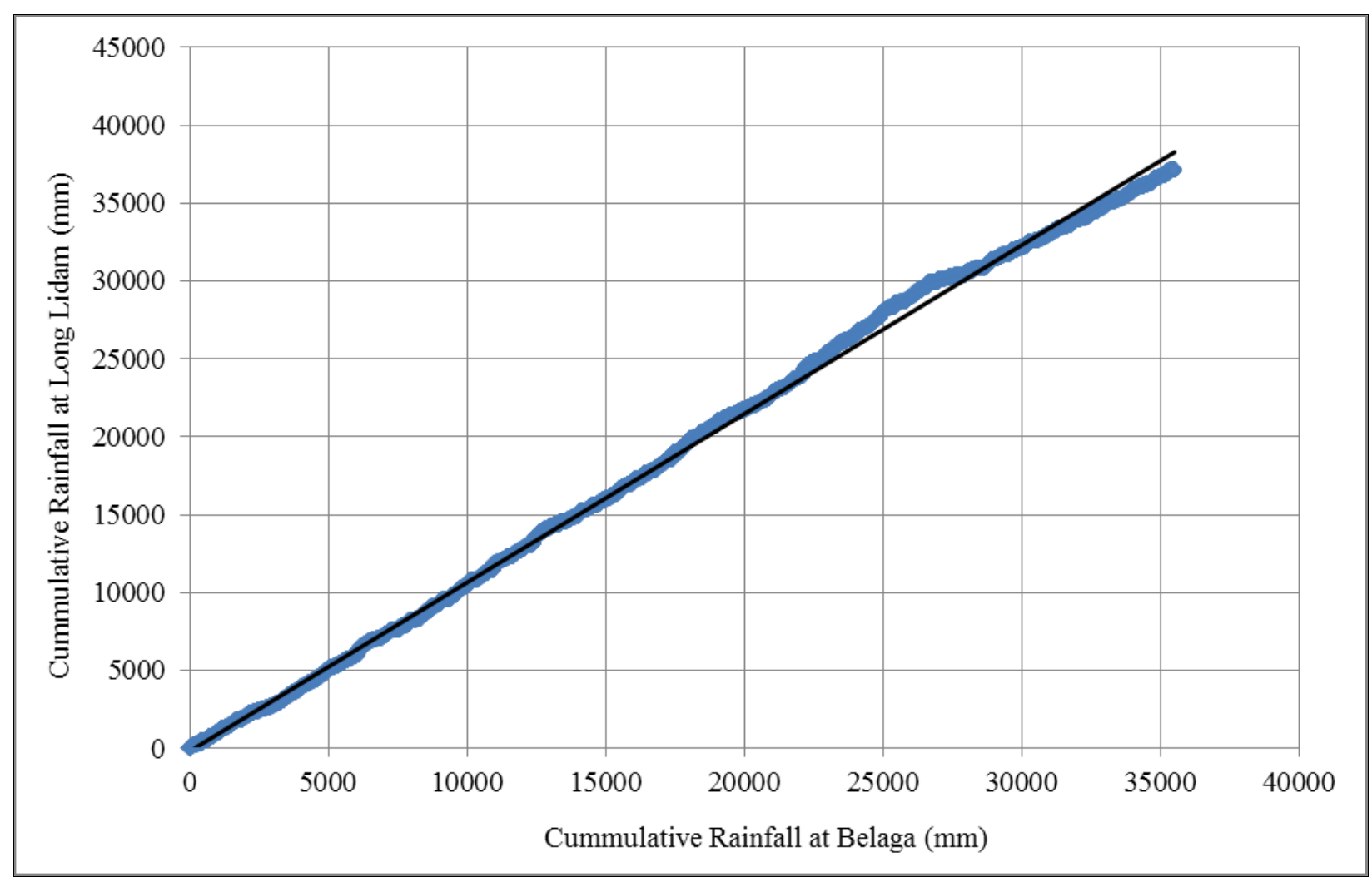

Figure 2 Double Mass Curve Between Long Lidam and Belaga Rainfall Data

\subsection{Infilling Missing Rainfall Data}

Daily rainfall data are one of the basic inputs in hydrological analysis. However, most daily rainfall data series are too short to perform reliable and meaningful analyses and possess significant number of missing records [6]. There are few missing period in the Long Lidam rainfall data which required infilling to ensure a continuous data of daily rainfall would be available for a more consistent estimation of PMP. A double mass curve has shown that Long Lidam station with Belaga station have constant proportionality in the rainfall series. Thus, infilling of missing data is carried out through direct interpolation based on the daily rainfall data of Belaga rainfall station. From the relationship, long term daily rainfall series of 33 years for Long Lidam from 1981 to 2013 was obtained.

\subsection{Estimation of PMP by Hershfield Statistical Method}

Comprehensive review of procedures to estimate PMP has been presented in the Water Meteorological Organization (WMO) manual. However, PMP estimates are still regarded as approximations, whose accuracy and reliability depends largely on the amount and quality of the data available. This paper uses a statistical method developed by Hershfield (1965) [7] based on a general frequency equation by Chow (1951) [8].

Statistical procedures for estimating PMP may be employed wherever sufficient precipitation data are available, and are particularly useful where other such meteorological data as dew point and wind records are not available. Another procedure is based on the meteorological approach. The meteorological approach consists essentially of moisture maximization and transposition of observed storms. Wind maximization is sometimes employed.

The statistical method is recommended for basins less than $1000 \mathrm{~km}^{2}$, but has been used for larger areas for quick estimation [1]. Equation (1) shows the general frequency equation for estimating the PMP value for a station;

$$
\mathrm{X}_{\mathrm{PMP}}=\mathrm{X}_{\mathrm{n}}+\mathrm{K}_{\mathrm{m}} \cdot \mathrm{S}_{\mathrm{n}}
$$

Where, $X_{P M P}$ is maximum observed rainfall amount for a station, $X_{n}$ is the mean for the series of $n$ annual rainfall values, $S_{n}$ is the standard deviation for the series of $n$ annual rainfall values, $K_{m}$ is the frequency factor which varies with different frequency distribution.

\section{RESULTS AND DISCUSSION}

Derivation of the point PMP value was done from the annual rainfall series for 24-hour precipitation at Long Lidam rain gauge station, the only station under the catchment. The frequency factor, $\mathrm{K}_{\mathrm{m}}$ for the 24-hour duration was obtained from [1]. Adjustments were made to the extreme value, $X_{\mathrm{PMP}}$ by taking into consideration the maximum observed event within the 


\section{UNIMAS e-Journal of Civil Engineering}

historic sequence, the length of available record, and the time period at which data are recorded as suggested in the WMO manual. The annual maximum daily rainfall was extracted from the long term data series as shown in Figure 3.

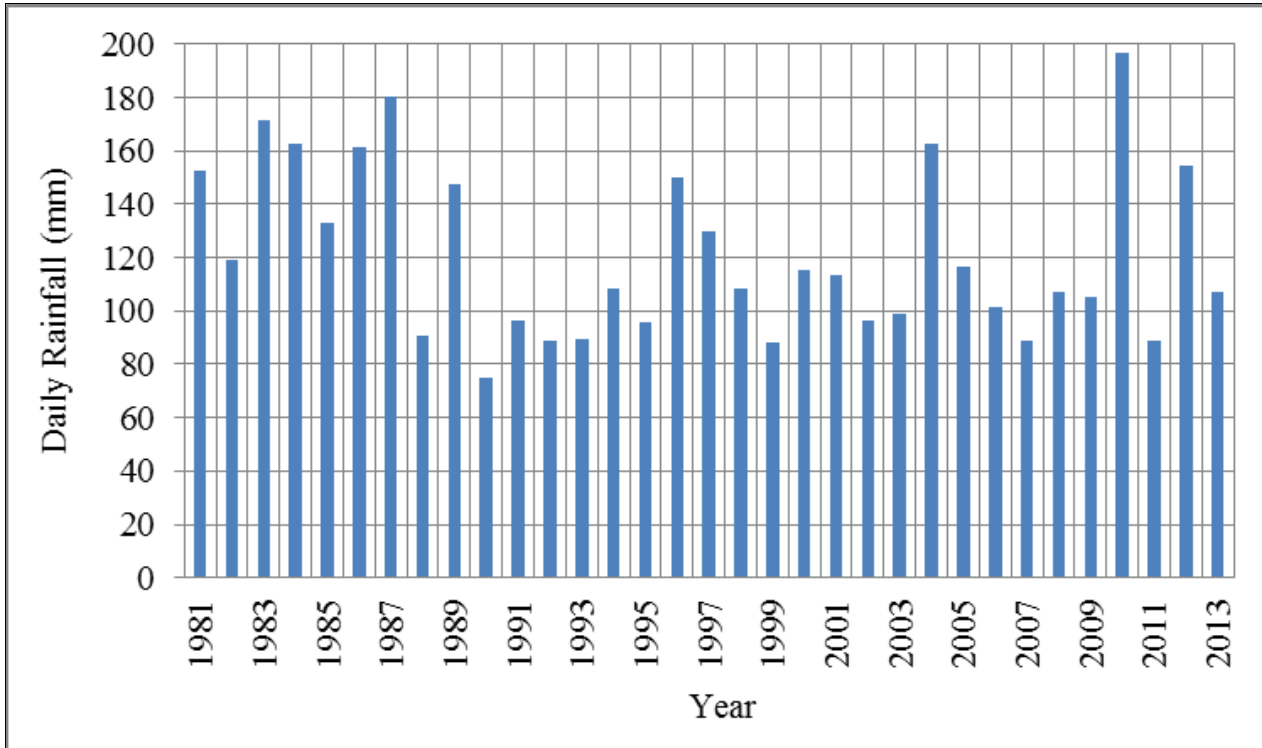

Figure 3 Maximum Daily Rainfall at Lidam Rain Gauge Station (1981-2013)

Table 2 Statistical parameters and PMP value estimated for the Linau River Basin.

\begin{tabular}{|l|c|}
\hline Item & Value \\
\hline No. of years & 33 \\
\hline$\overline{\mathrm{x}}_{\mathrm{n}}$ & 121 \\
\hline $\mathrm{S}_{\mathrm{n}}$ & 32 \\
\hline$\overline{\mathrm{x}}_{\mathrm{n}-\mathrm{m}}$ & 119 \\
\hline $\mathrm{S}_{\mathrm{n}-\mathrm{m}}$ & 29 \\
\hline$\overline{\mathrm{x}}_{\mathrm{n}-\mathrm{m}} \overline{\mathrm{x}}_{\mathrm{n}}$ & 0.98 \\
\hline $\mathrm{S}_{\mathrm{n}-\mathrm{m}} / \mathrm{S}_{\mathrm{n}}$ & 0.92 \\
\hline Adjustment for mean & \\
\hline $\begin{array}{l}\text { Adjustment coefficient of mean of annual series from Figure } 4.2 \text { in } \\
\text { WMO (2009) }\end{array}$ & 1.01 \\
\hline $\begin{array}{l}\text { Adjustment coefficient of mean of annual series for length of record } \\
\text { from Figure 4.4 in WMO (2009) }\end{array}$ & 1.007 \\
\hline Adjustment mean & 123 \\
\hline Adjustment for $\mathbf{S}_{\mathbf{n}}$ & \\
\hline $\begin{array}{l}\text { Adjustment coefficient of standard deviation of annual series for } \\
\text { maximum observed rainfall from Figure 4.3 in WMO (2009) }\end{array}$ & 1.03 \\
\hline $\begin{array}{l}\text { Adjustment coefficient of standard deviation of annual series for } \\
\text { length of record from Figure 4.4 in WMO (2009) }\end{array}$ & 1.026 \\
\hline Adjusted $\mathrm{S}_{\mathrm{n}}$ & 34 \\
\hline PMP & $\mathbf{6 9 1}$ \\
\hline $\mathrm{K}_{\mathrm{m}}$ from Figure 4.1 in WMO (2009) & 14.4 \\
\hline PMP (mm) & 611 \\
\hline Adjustment of the time interval from Figure 4.5 in WMO (2009) \\
\hline Final PMP (mm) & 1.13 \\
\hline
\end{tabular}




\section{UNIMAS e-Journal of Civil Engineering}

A summary of the PMP results is presented in Table 2. As shown, the final areal PMP for a 24-hour precipitation resulted to a distribution of $691 \mathrm{~mm}$. The estimated PMP value for Linau River basin using statistical method is high. This is mainly due to occurrence of very rare events in recorded period i.e the maximum daily rainfall during 2010 was noted as $197 \mathrm{~mm}$ which is very rare event.

\section{CONCLUSIONS AND RECOMMENDATIONS}

Since statistical method has the advantage of taking into account actual precipitation data and its application is simple and fast, after considering the data resources available, it was decided to use statistical method for estimation of 24-hour PMP.

Statistical procedure is based on the transposition and maximization of historical precipitation (annual maximum precipitation series). It yields only point values of PMP and use generalized curves based on data from climatically similar regions which introduce additional source of error.

Point values are often assumed to be applicable to area up to $25 \mathrm{~km}^{2}$ without reduction [1] unless converted to areal PMP by applying appropriate areal reduction factor. WMO (2009) provide the guideline for areal reduction factor upto a catchment of $1000 \mathrm{~km}^{2}$. And there is a need to look into other approaches for catchments more than $1000 \mathrm{~km}^{2}$.

Storm precipitation data could affect calculation of mean and standard deviation values. Length of record should be considered too. A long record will yield generally more reliable PMP estimates than will a short record of comparable quality. In other words, frequency distribution of extreme values is generally skewed to the right and therefore, correcting such events is recommended in PMP statistical estimates. Thus estimating PMP by this method can create conspicuous errors in basins under study. By considering the recommendations of WMO (2009), in case of availability of meteorological data, physical method yields in better results than the statistical method.

\section{ACKNOWLEDGMENT}

This study was conducted as a part of a project under Hydropower Development Division of Sarawak Energy Berhad (SEB). The Authors would like to thank the Department of Irrigation and Drainage, Sarawak, Malaysia (DID) for providing the related data access to perform this study.

\section{REFERENCES}

[1] WMO, 2009. "Manual for Estimation of Probable Maximum Precipitation (PMP)”, Publication No. 1045, World Meteorological Organization, Geneva, 2009

[2] M. C. Casas, R. Rodriquez, M. Prohom, A. Gazquez and A. Redano. (2010). "Estimation of the probable maximum precipitation in Barcelona (Spain)”. Int. J. Climatol. [Online]. DOI: 10.1002/joc.2149. Available: www.interscience.wiley.com

[3] J. K. Searcy and C. H. Hardison, "Double-mass curve," Manual of Hydrology: Part 1. Geological Survey Water-Supply Paper 1541-B, 1960.

[4] Norconsult, 2014, "Pelagus Hydroelectric Project - Concept Report".

[5] Entura, 2010, "Bakun Hydroelectric Project - Technical Risk Due Diligence Report".

[6] M. M. Hasan and B.F.W. Croke, "Filling gaps in daily rainfall data: a statistical approach," in $20^{\text {th }}$ Int. Congr. on Modelling and Simulation, Adelaide, 2013, pp. 380-386

[7] D. M. Hershfield, "Method of estimating probable maximum precipitation," J. Am. Water Works Association, No.57, 1965, pp. 965-972

[8] V. Chow, "A general formula for hydrologic frequency analysis," Trans. Am. Geophys. Union, No.32, 1951, pp. 231-237 